\title{
A húgyhólyag urothelialis daganatainak molekuláris alcsoportbeosztása és annak klinikai vonatkozásai
}

\author{
Szarvas Tibor dr. ${ }^{1,2 *}$ - Oláh Csilla ${ }^{1 *}$ - Riesz Péter dr. ${ }^{1}$ \\ Géczi Lajos dr. ${ }^{3}$ - Nyirády Péter $d r{ }^{1}$ \\ 'Semmelweis Egyetem, Általános Orvostudományi Kar, Urológiai Klinika, Budapest \\ ${ }^{2}$ Essen-Duisburgi Egyetem, Urológiai Klinika, Essen, Németország \\ ${ }^{3}$ Országos Onkológiai Intézet, Budapest
}

\begin{abstract}
A molekuláris biológia és a bioinformatika fejlődése által lehetőség nyílt a leggyakrabban előforduló daganatok - köztük az izominvazív húgyhólyagrákok - molekuláris hátterének teljes feltérképezésére. Ennek következtében az elmúlt évek során számos, a tumorok génexpressziós és fehérjemintázata alapján történő alcsoportbeosztás látott napvilágot az urothelialis húgyhólyagrákok molekuláris alapon történő elkülönítésére. A közelmúltban megszületett egy széles körű konszenzuson alapuló klasszifikáció, amely hat molekuláris alcsoportot különít el egymástól, és a jövőben jelentősen befolyásolhatja a terápiás döntéshozatalt is. Ezzel párhuzamosan az izominvazív húgyhólyagrák gyógyszeres terápiája is sokrétúbbé vált, hiszen a továbbra is az első vonalban alkalmazott perioperatív ciszplatinalapú kemoterápián túl a közelmúltban elérhetővé váltak új, checkpointgátló készítmények a kemoterápiára rezisztens, illetve alkalmatlan betegek számára. Továbbá ígéretes kezelési lehetőséget jelentenek az FGFR-támadáspontú szerek is. A terápiás fegyvertár bővülésével a molekuláris alcsoportok elkülönítése lényeges szerepet kaphat a legoptimálisabb kezelés kiválasztásában. Jelen munkánkban összefoglalást nyújtunk az izominvazív húgyhólyagrák molekuláris alcsoportbeosztásáról, valamint annak klinikai jelentőségéról.
\end{abstract}

Orv Hetil. 2019; 160(42): 1647-1654.

Kulcsszavak: izominvazív húgyhólyagrák, molekuláris alcsoport, ciszplatinalapú kemoterápia, checkpointgátló, génexpressziós mintázat

\section{Molecular subtype classification of urothelial bladder cancer and its clinical relevance}

\begin{abstract}
Current advances in molecular techniques and bioinformatics allowed the analysis of complex molecular patterns in various cancers including muscle-invasive bladder cancer. As a consequence, in the last few years numerous gene- and protein expression-based molecular classifications have been recommended. Recently a comprehensive consensus classification for muscle-invasive urothelial bladder cancer has been published, distinguishing 6 subgroups with a potential impact on clinical decision-making. At the same time, the therapeutic landscape of muscle-invasive bladder cancer becomes increasingly differentiated as novel checkpoint inhibitors have been available for cisplatin-ineligible and/or resistant patients. Furthermore, promising results have been obtained with FGFR targeting agents. Therefore, molecular subtyping will probably have a crucial role in individualized therapeutic decision-making in bladder cancer. In the present work, we summarize the evolution, recent advances and potential therapeutic relevance of molecular subclassifications in bladder cancer.
\end{abstract}

Keywords: muscle-invasive bladder cancer, molecular subtypes, cisplatin-based chemotherapy, checkpoint inhibitor, gene expression pattern

Szarvas T, Oláh Cs, Riesz P, Géczi L, Nyirády P. [Molecular subtype classification of urothelial bladder cancer and its clinical relevance]. Orv Hetil. 2019; 160(42): 1647-1654.

(Beérkezett: 2019. június 19.; elfogadva: 2019. július 19.)

*A két szerző egyenlő mértékben járult hozzá a cikk megszületéséhez. 


\section{Rövidítések}

EGFR = (epidermal growth factor receptor $)$ epidermális növekedési faktor receptor; EMT = epithelialis-mesenchymalis átmenet; FDA $=$ (U. S. Food and Drug Administration) az Amerikai Egyesült Államok Élelmiszer-biztonsági és Gyógyszerészeti Hivatala; FGFR = (fibroblast growth factor receptor) fibroblast növekedési faktor receptor; PD-1 = (programmed cell death 1) programozott sejthalál-1; PDL-1 = (programmed death-ligand 1) a programozott sejthalál-1 ligandja; RNS = ribonukleinsav; SCC $=$ (squamous cell carcinoma) laphámsejtes carcinoma; TCGA = (The Cancer Genome Atlas) Rákgenom Atlasz; UNC $=($ University of North Carolina at Chapel Hill $)$ Chapel Hill-i Észak-karolinai Egyetem

A húgyhólyag urothelialis daganata a húgyutakat érintő leggyakoribb daganat. A Nemzeti Rákregiszter adatai alapján Magyarországon évente körülbelül 3000 új húgyhólyagrákos megbetegedést diagnosztizálnak, a húgyhólyagrák miatti halálozás pedig évi 900 körül alakul [1]. A daganatok 70-80\%-a a diagnózis idején csupán a hólyag felső urothelrétegét érinti. Az ilyen nem izominvazív daganatok ugyan gyakran, akár az esetek 70-80\%-ában is kiújulnak, de progressziójuk ritka. Ebből adódóan a nem izominvazív húgyhólyagrákok prognózisa igen kedvező, a betegek 5 éves túlélése 90\% felett alakul. E betegek kezelésére többnyire elegendő a transurethralis reszekció. Ezzel szemben az izominvazív daganatok, melyek a bazális membránt áttörve a hólyag izmos falát is beszűrik, jelentősen nagyobb kockázatot jelentenek. Az 5 éves túlélés a radikális sebészi terápia ellenére is csupán $50 \%$ körül alakul [2]. Az izominvazív urothelialis daganatok a klinikai viselkedésüket tekintve meglehetősen változatosak. A betegek körülbelül fele jól reagál a radikális sebészi terápiára, míg mások jellemzően a mütétet követő két éven belül metasztatikus progreszszió következtében elhaláloznak [3]. Az izominvazív daganatok a szisztémás kezelésre adott válasz tekintetében is nagy heterogenitást mutatnak, hiszen a betegek csupán fele reagál a ciszplatinalapú kezelésre [4]. A perioperatív ciszplatinalapú kemoterápia több mint 30 éve az elsőként választandó kezelés lokálisan előrehaladott és metasztatikus izominvazív húgyhólyagrákban. Bár a jelenleg érvényes irányelvek mind radikális cystectomia utáni adjuváns, mind pedig a mútét előtti neoadjuváns alkalmazását ajánlják, széles körben mégis csak az adjuváns kezelés terjedt el igazán. Ennek oka, hogy a neoadjuváns kemoterápia a kezelt hólyagrákos betegek csupán 5\%-ánál képes javítani az 5 éves túlélést [5]. Másrészt a neoadjuváns alkalmazás a sebészi beavatkozást szükségszerúen több héttel eltolja, ami egy közelmúltban publikált tanulmány szerint a ciszplatinrezisztens betegek esetében rövidebb túlélést okoz, mint a késedelem nélkül elvégzett radikális mütét [6]. Ezek alapján érthető, hogy a ciszplatinalapú kemoterápia hatékonyságának előrejelzése kiemelkedő fontosságú lenne a helyes terápiás stratégia megválasztásában. Ezen túl a ciszplatinterápia hatékonyságának előrejelzése az új checkpoint (ellenőr- zőpont)-gátló kezelések megjelenésével még inkább égető szükségúvé vált. A PDL-1-gátló és PD-1-gátló szerek a jelenlegi irányelvek szerint a másodvonalban ciszplatinrezisztens, valamint az első vonalban a ciszplatinkezelésre alkalmatlan betegeknek adhatók [5, 7]. A ciszplatinkezelés hatékonyságának előrejelzése tehát utat nyithatna a checkpointgátlók haladéktalan alkalmazásának olyan esetekben, amelyekben a ciszplatinkezelés várhatóan nem lesz hatékony.

A fenti ismeretek tükrében központi kérdés, hogy mi okozza az urothelialis daganatok különböző kezelésre adott eltérő válaszait. A molekuláris biológia és a bioinformatika elmúlt években történt robbanásszerü fejlődésével lehetőség nyílt a tumorok molekuláris hátterének teljes feltárására. Ebben vezető szerepe volt a TCGA(The Cancer Genome Atlas) projektnek, mely célul tűzte ki, hogy a legmodernebb nagy áteresztőképességü vizsgálómódszerek alkalmazásával, nagy számú tumorminta felhasználásával feltérképezze a leggyakoribb daganatok teljes molekuláris hátterét, és ezt ingyenes formában mindenki számára elérhetővé tegye. Ehhez teljesexomszekvenálás mellett transzkriptom és metilációs szekvenálást, valamint proteomikai vizsgálatokat is végeztek, amihez a részletes klinikai és követési adatokat is elérhetővé tették. Eddig 33 tumorféleségben szenvedő összesen mintegy 11000 betegen végezték el a vizsgálatokat, melyek eredményeit tumortípusonként publikálták. A húgyhólyagrák esetében 2014-ben 131 izominvazív daganatból kapott eredményeket közöltek [8], majd a 2017-ben továbbduzzasztott vizsgálatban már 412 betegből származó eredményeket publikáltak [9]. Az ezen vizsgálatokból adódó óriási mennyiségű információ klinikai szempontból történő értelmezése jelenleg is nagy erőkkel folyik.

\section{A húgyhólyagrák molekuláris alcsoportjai}

\section{Az elsö beosztások (luminális, bazális, p53-szeri")}

Az izominvazív hólyagrákok génexpressziós mintázatának átfogó elemzésével (ún. hierarchikus klaszteranalízis segítségével) Damrauer és mtsai azt találták, hogy e daganatok két nagy csoportra oszthatók. Az egyik csoporthoz tartozó „luminális” tumorokban olyan gének fejeződnek ki (KRT19, KRT20, GATA3, FOXA1), melyek jellemzően a hólyag lumene felé eső, tehát a felszínen található urothelsejtekre jellemzők, míg a másik, „bazális" csoporthoz tartozó esetekben inkább az urothelium bazális sejtrétegeihez hasonló génexpressziós (KRT5, KRT14) mintázat volt megfigyelhető, valamint jellemzően mesenchymalis markerek (SNAI, TWIST) fejeződtek ki. Ezek alapján valószínú, hogy e két altípushoz való tartozást nagyrészt az dönti el, hogy a daganat az urothelium mely sejtrétegéből indult ki. A két csoport között prognosztikai szempontból is lényeges különbség volt, hiszen a luminális daganatok szignifikánsan hosz- 
szabb túlélést mutattak a bazális csoportba tartozókhoz képest [10]. Ezzel a felfedezéssel nagyjából egy időben egy másik kutatócsoport, egy az előzőtől független betegcsoport mintáit vizsgálva, megerősítette a „luminális" és „bazális” alcsoportok létezését izominvazív húgyhólyagrákokban. Ugyanakkor Choi és mtsai egy további, ún. „p53-szerú” csoportot is elkülönítettek, amely mind luminális, mind pedig bazális mintázatot mutatott, viszont jellemzően olyan gének emelkedett expressziója jellemezte, melyek a vad típusú (tehát nem mutálódott) p53-gén jelenléte esetén termelódnek. Ennek az alcsoportnak a klinikai jelentősége abból adódik, hogy az idetartozó daganatok rosszul reagálnak a kemoterápiás kezelésre [11]. Később kiderült, hogy a „p53-szerú” csoport jellemzó génexpressziós mintázata nem a daganatsejtektől, hanem az azok környezetében elhelyezkedő stroma- (simaizom-, kötőszöveti és immun-) sejtektől származik [12]. Az első két munka közlése után jelentős figyelem irányult az izominvazív hólyagrákok molekuláris alcsoportjainak kutatására, melynek eredményeképpen egyre több mintán végezték el ezek vizsgálatát, és egyre több új alcsoport került felfedezésre. Az MD Anderson-féle csoportosításnál szintén a „luminális”, a „bazális” és a „p53-szerú” alcsoportokat különítették el egymástól [13].

\section{$A z U N C$-beosztás}

Az Észak-karolinai Egyetem (UNC) munkatársai a „luminális” és „bazális” csoportok mellett elkülönítettek egy harmadik, „klaudinszegény” alcsoportot, mely génexpressziós mintázatában sem a bazális, sem pedig a luminális differenciációra jellemző markereket nem termeli (ezért „dupla negatívnak” is szokták nevezni), viszont gyakori köztük az epithelialis-mesenchymalis átmenet (EMT), és egyben gyakran emelkedett PDL-1-expressziót mutatnak. Az ehhez a csoporthoz tartozó daganatok a bazálishoz hasonlóan rossz túlélési esélyeket mutatnak, viszont magas PDL-1-expressziójukból feltételezhető, hogy a „klaudinszegény” alcsoport reagál az immunterápiára [14].

\section{A TCGA I. beosztás}

A TCGA-projekt részeként 2014-ben 131 izominvazív húgyhólyagdaganatot vizsgáltak RNS-szekvenálással, mellyel négy különbözô molekuláris alcsoportot határoztak meg (TCGA I., II., III. és IV.). Az I. és II. klaszterbe sorolt daganatok luminális altípusúak, papillaris növekedésúek, míg a III. és IV. klaszterbe sorolt daganatok bazális jellegeket hordoznak. A III. klaszterhez tartozó daganattípus nagy mennyiségben expresszál citokeratinokat (KRT14, KRT5), és magas az EGFRexpressziója. A IV. klaszterbe sorolt pedig a korábban leírt „klaudinszegény” alcsoporttal mutat hasonlóságokat $[8]$.

\section{A TCGA II. beosztás}

2017-ben megjelent a kibővített TCGA-vizsgálat, amely az eddigi vizsgálatok közül a legnagyobb esetszámot vonultatta fel. Az itt közölt beosztás a bazális alcsoport megtartása mellett a luminális altípust további három alcsoportra bontotta: „luminális papillaris”, „luminális” és „luminális infiltrált”, mely utóbbi a korábbi TCGA II. klaszterrel állítható párhuzamba, továbbá a más csoportosításokból már ismert „p53-szerü” és „klaudinszegény" molekuláris alcsoportokhoz is hasonlóságot mutat. Az ezekbe az alcsoportokba sorolt daganattípusok esetében valószínúleg kevésbé hatékony a ciszplatinalapú kemoterápia. A „bazális” csoportban emelkedett volt a PDL-1 fehérje génexpressziója, ami az immunterápia eredményességére enged következtetni. Ezenfelül pedig azonosított a vizsgálat egy új, viszonylag ritka - az izominvazív daganatok csupán 5\%-át kitevő -, ám igen rossz prognózisú ún. „neuronalis” vagy „neuroendokrinszerú" csoportot is. Az idetartozó daganatok szövettani megjelenésüket tekintve urothelialis daganatok, de olyan géneket expresszálnak, melyek a neuronalis szövetekre, illetve a neuroendokrin daganatokra jellemzők. Ezen alcsoport esetében hatékony kezelés lehet a kombinált ciszplatin/etopozid kemoterápia [9].

\section{A Lund-féle beosztás}

A Lund-féle csoportosításban öt különböző molekuláris alcsoportot különítettek el. Az „Urobasal A” altípus prognózisa a legkedvezőbb, a „genetikailag instabil” és „infiltrálódott” molekuláris alcsoportoké közepes, míg az „Urobasal B” és az ún. „squamosus” carcinoma szerú (SCC) altípusé a legrosszabb. Az alcsoportokat eltérő génexpresszió, valamint immunhisztokémiai markerek alapján osztották fel. Az „Urobasal A”-ra jellemző a magas FGFR3-génexpresszió, ami e daganatok korábbi nem izominvazív eredetét valószínúsíti. Továbbá a normális urothelsejtekre jellemző KRT5, KRT13, KRT15 és KRT20 génexpressziós profilt mutat, illetve gyakran alacsony malignitású, és kedvezőbb prognózissal jár együttt. Ezzel szemben a "genetikailag instabil” alcsoport kevésbé ôrzi meg epithelialis jellegét, gyakori benne a $p 53$ mutáció, és csökkent expressziót mutat olyan géneknél, amelyek a sejt-sejt kapcsolat kialakításában játszanak szerepet. Az SCC-alcsoportban emelkedett volt a bazális sejtekre jellemző keratinexpresszió (KRT4, KRT6, KRT14, KRT16). Az „Urobasal B” számos hasonló tulajdonsággal rendelkezik, mint az „Urobasal A”, ellenben gyakori $p 53$-mutációt és az SCC-alcsoportra jellemző keratin-génexpressziós mintázatot is mutat. Az „infiltrálódott” molekuláris alcsoport pedig hasonló a más csoportosításokban lévő p53-szerúvel [15]. A csoportosítást a késóbbiekben kibővítették, és a következő alcsoportokat különítették el: az „urothelialist” és a „genetikailag instabilt", amelyek luminális típusúak, és a korábbi csoportosításban már szintén jelen lévő „bazális/ 
Damrauer et al.

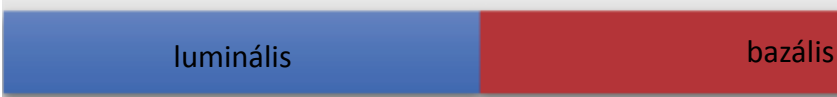

Choi et al.

luminális p53-szerű bazális

MDA

luminális p53-szerü bazális

UNC

$\begin{array}{lll}\text { luminális } & \text { blaudin- } \\ & \text { szegény }\end{array}$

TCGA I.

I.

II.

III.

IV.

TCGA II.

\begin{tabular}{|c|c|c|c|c|}
\hline $\begin{array}{l}\text { luminális } \\
\text { papillaris }\end{array}$ & luminális & $\begin{array}{l}\text { luminális } \\
\text { infiltrált }\end{array}$ & bazális/SCC & $\mathrm{NE}$ \\
\hline urothelialis & \multicolumn{2}{|c|}{$\begin{array}{l}\text { genetikailag mesen- } \\
\text { instabil chymalis }\end{array}$} & bazális/SCC & NE \\
\hline $\begin{array}{ll}\text { luminális ne } \\
\text { papillaris lun }\end{array}$ & $\begin{array}{l}\text { ec. instabil } \\
\text { is luminális }\end{array}$ & $\begin{array}{l}\text { stroma- } \\
\text { gazdag }\end{array}$ & bazális/SCC & NE \\
\hline
\end{tabular}

1. ábra $\mid \begin{aligned} & \text { Az izominvazív húgyhólyagrákok génexpressziós alapon javasolt csoportbeosztásai a különböző kutatócsoportok ajánlásai alapján } \\ & \mathrm{NE}=\text { neuronalis/neuroendokrin alcsoport }\end{aligned}$

SCC-szerü” alcsoportot. Ezenfelül bevezették a „mesenchymalisszerü” elnevezést, amely a korábbi „infiltrálódott” molekuláris alcsoport megfelelője, illetve a „neuroendokrinszerü" molekuláris alcsoportot [16], amely a kibővített TCGA-csoportosításban is jelen van.

Több kutatócsoport egymástól függetlenül sorolta be az izominvazív húgyhólyagrákot molekuláris alcsoportokba, melyek között jelentős átfedés látható (1. ábra). Az alcsoportok elkülönítése azért szükségszerú, mert eltérő prognózist mutatnak, és eltérően reagálhatnak a különböző kezelésekre is. A luminális típusba tartozó betegek túlélési esélyei a legjobbak, annak ellenére is, hogy kevésbé reagálnak a kemoterápiára. A bazális, mint a TCGA III. és az SCC-szerü alcsoportokba sorolt betegek túlélési esélyei rosszabbak, a ciszplatinalapú kemoterápiára adott válaszuk szempontjából eddig ellentmondásos eredmények láttak napvilágot. A szintén bazális típusú „klaudinszegény” és TCGA IV. csoportok is rossz túlélési esélyekkel párosulnak. Ugyanez elmondható a „neuronalis/neuroendokrin”, a TCGA II., a p53-szerü és a Lund-féle csoportosításban jelen lévő „genetikailag instabil” és „infiltrálódott/mesenchymalis” alcsoportok esetében is, miszerint rosszabb prognózissal rendelkeznek [17].

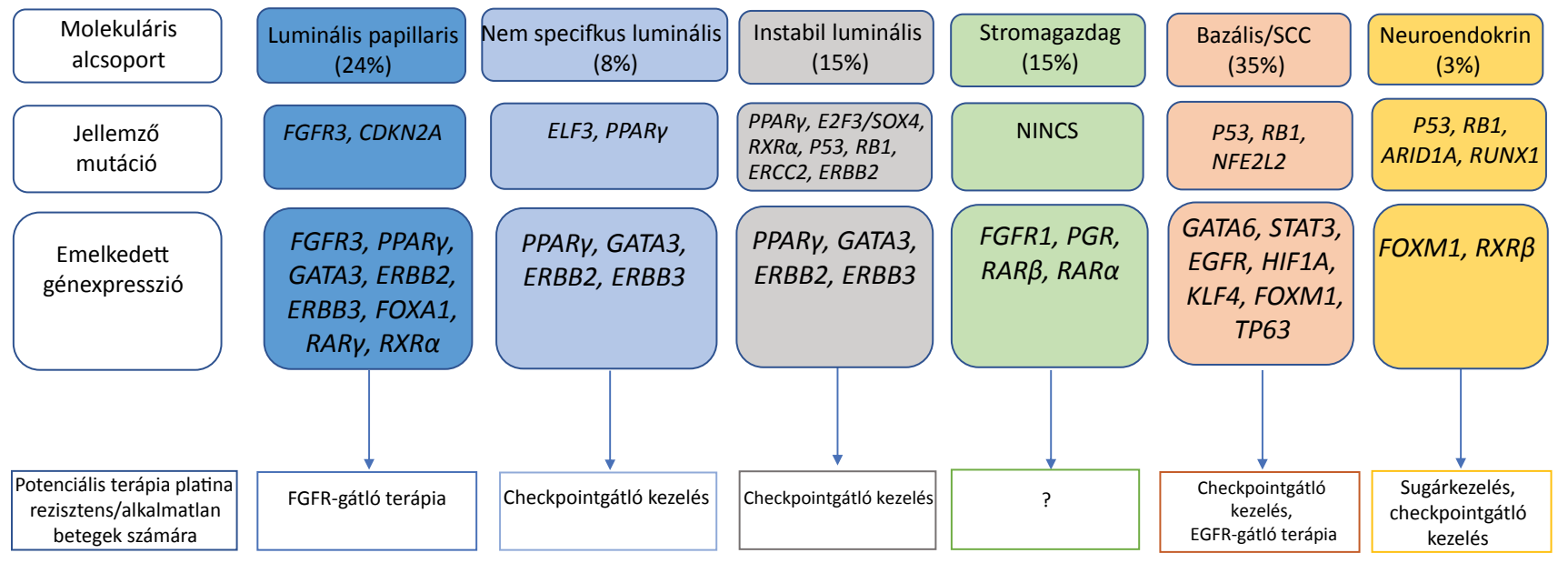

2. ábra $\quad$ A konszenzus alapján meghatározott molekuláris alcsoportbeosztás az adott csoportokra jellemző mutációk, emelkedett expressziójú gének és a feltételezhetôen hatékony terápiák feltüntetésével

EGFR = epidermális növekedési faktor receptor; FGFR = fibroblast növekedési faktor receptor 


\section{A konszenzusbeosztás}

Az eddigi leírásokból látható, hogy az alcsoportbeosztások a vizsgálatok számának növekedésével egyre bonyolultabbá váltak, ami természetesen alkalmazhatóságukra is kedvezőtlen hatással volt. Ezért a terület vezető kutatói egymással egyeztetve kialakítottak egy közös megegyezésen alapuló besorolást, melyet a közelmúltban 1750 mintán validáltak [18]. Ennél a konszenzuson alapuló csoportbeosztásnál figyelembe vették a tumorok hisztológiai, klinikai és onkológia tulajdonságait, illetve stromába való beágyazottságukat. Ezek alapján 6 molekuláris alcsoportot különítettek el: „luminális papillaris” (24\%), „nem specifikus luminális” (8\%), „instabil luminális" (15\%), „stromagazdag” (15\%), „bazális/SCC” (35\%) és „neuroendokrinszerü” (3\%). Ez a besorolás számos átfedést tartalmaz más csoportbeosztásokkal, de a leginkább a Lund-féle és a kibővített TCGA-csoportosításra hasonlít (1. és 2. ábra).

A „bazális/SCC” alcsoportban a többi alcsoporthoz képest nagyobb arányban szerepelnek nők, és a diagnóziskor e csoportban mutatható ki a legmagasabb invazivitás. E csoport életkilátásai a luminális alcsoportokhoz képest gyengébbek, és csak a „neuroendokrinszerü” daganatokénál tekinthetők kedvezőbbnek. Az alcsoport jellemzésére az emelkedett KRT14, KRT5/6, EGFR és STAT3 génexpressziók használhatók. A leggyakrabban mutálódott gének pedig a $p 53$, az RBI (együtt csak ritkábban) és a NFE2L2 transzkripciós faktor, amely a gyulladásos folyamatoknál szerepet játszó fehérjék génjeinek expresszióját szabályozza. A csoport kettős neve abból adódik, hogy nem csupán az urothelsejtek bazális sejtjeire jellemző géneket, hanem a laphámsejtes (squamous) differenciációt irányító géneket is erôsen expresszálják. Érdekes módon e csoport génexpressziós mintázata a fej-nyaki régió és a tüdő laphámrákos elváltozásaihoz mutat nagyfokú hasonlóságot. Az első terápiára vonatkozó retrospektív adatok azt mutatták, hogy ezen alcsoport esetében a ciszplatinalapú kezelés hatékony lehet, ezt az észrevételt azonban egy újabb, ugyancsak retrospektív vizsgálat nem tudta megerősíteni [17, 19]. Továbbá a PDL-1-gátló atezolizumab engedélyezéséhez vezető klinikai vizsgálatban részt vevő betegek mintáin elvégzett ugyancsak retrospektív vizsgálat szerint a „bazális" alcsoportba sorolt betegek a többi alcsoporthoz képest kissé jobban reagáltak a checkpointgátló kezelésre [20].

A „luminális papillaris” altípus daganatai papillaris morfológiát mutatnak, génexpressziós profiljukra jellemző a PPAR $\gamma, G A T A 3, E R B B 2, E R B B 3, F O X A 1, R A R \gamma$ és $R X R \propto$ megnövekedett expressziója. Emellett jellemző az FGFR3 aktiváló mutációja, ezáltal magasabb génexpressziója és a $C D K N 2 A$ inaktiváló mutációja, melyet a 9-es kromoszómán bekövetkező deletio okoz. Az e csoportba tartozó izominvazív daganatok nagy valószínüség szerint a felszínes papillaris daganatok progressziójával alakulnak ki. Ezt támasztja alá az is, hogy a felszínes hó- lyagdaganatok génexpressziójuk alapján szinte kizárólag a luminális alcsoportok valamelyikéhez sorolhatók [21, 22]. Az elsó nagyobb retrospektív vizsgálat azt mutatta, hogy a neoadjuváns kemoterápia egyedül a bazális alcsoportban javítja az életkilátásokat [17]; az eredménnyel egybevágóan a konszenzusbesorolás szerint a „luminális papillaris" altípusok szintén rezisztensek a platinaalapú kemoterápiára. Ezzel összhangban a közelmúltban Pietzak és mtsai azt találták, hogy azok a betegek, akiknél a hólyagdaganat egy régebb óta ismert nem invazív papillaris daganat progressziója által válik izominvazívvá, kevésbé reagálnak a ciszplatinalapú terápiára, mint azok, akiknél már az első diagnózis idején izomra terjedő daganatot mutattak ki $[6,23]$. Ugyanakkor a csoportban jellemzően magas az FGFR3-aktivitás, aminek következtében ezt az altípust FGFR-gátló szerrel lenne érdemes megcélozni. Ezzel kapcsolatban fontos megjegyezni, hogy az FGFR-inhibitor erdafitinib 2019 áprilisában kapott FDA-engedélyt olyan lokálisan előrehaladott vagy metasztatikus húgyhólyagrákos betegek kezelésére, akik korábban átestek ciszplatinalapú kezelésen, és hordoznak FGFR2- vagy FGFR3-eltérést. A fentiekből következően a „luminális papillaris” csoport fog a legnagyobb arányban válaszolni az FGFR-gátló kezelésre [24-26]. Az erdafitinib mellett egy másik FGFR3-gátló szerrel, a vofatamabbal végzett fázis II-es vizsgálat előzetes eredményei azt mutatták, hogy a vegyület pembrolizumabbal kombinálva növelheti az immunterápia hatékonyságát, különösen a luminális alcsoportba sorolt betegek esetében [27].

A „nem specifikus luminális” altípusra ugyancsak jellemző a papillaris morfológia, ami mellett azonban gyakran in situ carcinoma is jelen van. Jellegzetes továbbá még a $P P A R \gamma$ aktiváló mutációja és megnövekedett génexpressziója, valamint a stromasejtekre jellemző génexpressziós mintázat is hangsúlyos. A luminális altípusok közül ez az altípus párosul a legrosszabb prognózissal. A legfrissebb adatok szerint ez a csoport jól reagál a checkpointgátló kezelésre [18].

$\mathrm{Az}$,instabil luminális” tumorok jellemzően az idősebb betegek körében fordulnak elő. Az idetartozó daganatok fontos jellemzője az igen magas mutációs ráta, mely mind a szomatikus mutációk magas számában, mind pedig a kópiaszám-eltérések magas arányában megnyilvánul. Erre az alcsoportra is jellemző a papillaris morfológia. Mindemellett, ahogyan a másik két luminális altípusnál is megfigyelhető, itt is magas a $P P A R \gamma$, GATA3, ERBB2 és ERBB3 gének expressziója. Ezenfelül ez az egyetlen luminális altípus, amelynél magas a $p 53$ és RBI mutációs aránya, továbbá megtalálható az ERCC2 DNS-hiba-javító gén inaktiváló mutációja, mely a ciszplatinterápia egyik legerósebb ismert pozitív prediktora [28, 29]. Az ERBB2-gén amplifikációja ugyancsak gyakori ebben a csoportban. Ismert, hogy az ERBB2-gén terméke, a Her2, emlődaganatoknál fontos terápiás célpont, így az anti-HER2-terápia bevethetősége természetesen felmerült olyan előrehaladott húgyhó- 
lyagdaganatok esetében, melyek e gén emelkedett expresszióját hordozzák. Sajnos az eddigi anti-Her2-kezeléssel elvégzett klinikai vizsgálatok nem igazoltak terápiás előnyt az emelkedett Her2-expressziójú húgyhólyagdaganatokban [30, 31]. Kamoun és mtsai szintén azt találták, hogy az „instabil luminális” alcsoport betegei jól reagálnak a checkpointgátló kezelésre [18].

A „stromagazdag” altípus azonosítására használt markerek jellemzően nem a tumorsejtektől, hanem az azokat körülvevő simaizom- és endothelsejtektől származnak. Ez az altípus rendelkezhet bazális és luminális tulajdonságokkal is, megkülönböztetése gyakorlatilag a szövetmintában jelen lévő stroma/tumor arány alapján történik. Ez az alcsoport tehát nem a daganatsejtekre jellemző (intrinszik) molekuláris tulajdonságait írja le, hanem inkább arról ad képet, hogy a daganatsejtek menynyire lazán infiltrálják a környezetükben lévő szöveteket [18]. Az altípusra jellemző az alábbi gének emelkedett expressziója: FGFR 1, PGR, RAR és RAR .

A „neuroendokrinszerü” alcsoporthoz sorolható daganatok az izominvazív hólyagdaganatok körülbelül 3\%át teszik ki, és igen rossz prognózisukkal tűnnek ki. Jellemző rájuk az emelkedett a FOXMI és RXRß génexpresszió, továbbá itt is megjelent a p53 és az $R B 1$ inaktiváló mutációja, amelyek azonban a tumorsejtek nagy százalékában együttesen fordulnak elő. Ennél az alcsoportnál a magas sejtciklus-aktivitásból és ezzel együtt jellemzően alacsony hypoxiaszignálból a sugárkezelés hatékonyságára következtethetünk [18]. Ezenkívül az IMvigor210 vizsgálat szerint a „neuroendokrinszerü" daganatok kiemelkedően jól reagáltak a PDL-1-inhibitor atezolizumabbal végzett terápiára. Ez annak ellenére is igaz, hogy ebben az alcsoportban alacsonynak bizonyultak az olyan, általában a checkpointgátló kezelésre adott kedvező válasszal pozitív összefüggést mutató paraméterek, mint az átlagos mutációs szám (tumor mutation burden) és a tumorban található CD8+ T-sejtek száma [20]. A magas p53 és $R B 1$ gének mutációs gyakorisága alapján további terápiás javaslat a kombinált ciszplatin/ etopozid kemoterápia, mely kezelés során jobb eredményeket értek el olyan betegek esetében, akiknél a hólyagdaganatok egy ritkán előforduló típusát (<1\%), a kissejtes carcinomát diagnosztizálták. Az ezen típusú hólyagdaganatokra szintén jellemző a magas $p 53$ és $R B 1$ mutációs gyakoriság [9, 32], mely összefüggés következtetni enged a kombinált ciszplatin/etopozid kezelés hatékonyságára a,neuroendokrinszerü” urothelialis daganatok kezelésekor.

Összességében a molekuláris alcsoportok a konszenzusbesorolás szerint is szignifikáns összefüggést mutatnak a prognózissal; a „luminális papillaris” altípus esetében a leghosszabb a túlélés, a másik két luminális, a „stromagazdag” és a „bazális/SCC” alcsoportnál rövidebb, míg a „neuroendokrinszerü” esetében a legroszszabb a betegség kimenetele. A ciszplatinalapú kemoterápiára adott válasz tekintetében egyelőre egyik altípus sem emelhető ki bizonyossággal, ellenben a checkpoint- gátló kezelésre a „nem specifikus luminális”, az „instabil luminális” és különösen a „neuroendokrinszeru”” tumorok adnak erős választ [18]. A „lumináris papillaris” csoporthoz tartozó tumorok várhatóan az anti-FGFR-kezelésre reagálnak jól, míg a bazális altípusban az EGFR-gátló terápia is hatékony lehet (2. ábra).

\section{Módszertani megfontolások}

A tumoron belüli heterogenitáson azt értjük, hogy egy daganatban egymástól eltérő tulajdonságokkal rendelkezô tumorsejt-populációk is jelen lehetnek. Ez a jelenség minden szövetből történő vizsgálat során technikai problémát jelenthet, hiszen megnehezíti a reprezentatív mintavételt. Ez a jelenség természetesen a molekuláris alcsoportok szintjén is megnyilvánul.

A Lund-féle csoportosítás alapján a „bazális/SCCszerü” esetek nagy százalékában kimutatták az „urothelialis" vagy a „genetikailag instabil” altípus jelenlétét. A két altípus együttes előfordulása magyarázatul szolgálhat a „bazális/SCC” eredetére, miszerint ez a típus az „urothelialis”, illetve a "genetikailag instabil” csoportokból származhat [33]. Ezzel ellentétben a többi molekuláris alcsoport esetében csak csekély számban fedeztek fel tumoron belüli heterogenitást.

A „bazális/SCC” típusnál altípusváltást is megfigyeltek a primer tumorhoz képest; a nyirokcsomókban az esetek 60\%-ában az „urothelialis” vagy a „genetikailag instabil” alcsoporthoz tartozó tumorokat azonosították a primer daganatra jellemző „bazális/SCC” helyett [34].

A molekuláris alcsoportbeosztás mindennapi rutingyakorlatban történő elterjedésének egyelőre gátat szab, hogy az eddigi alcsoportbeosztások transzkriptom szekvenálási adatokon alapulnak, amihez friss (nem formalinfixált) szövetből történő RNS-izolálásra van szükség. Ezt követi a több ezer gén RNS-szekvenálása és a nagy mennyiségü adat kiértékelése. A csoportbeosztás jelenleg alkalmazott módszere több mint 3000 gén expressziójának tekintetbevételét követeli meg. Összességében tehát e módszer munka- és költségigénye nem egyeztethető össze a rutinszerü felhasználással. A mindennapi rutinalkalmazás számára egy egyszerü, megbízható immunhisztokémiai módszer tûnik kézenfekvőnek. Ennek megfelelően történtek kísérletek a génexpressziós alapú Lund-klasszifikáció immunhisztokémiai módszerrel történő reprodukálására. A szerzők összesen 28 -féle fehérjemarker együttes vizsgálatát tartották szükségesnek öt alcsoport elkülönítésére, ami szintén nem nevezhető a rutinnal összeegyeztethetőnek [16]. Ugyanakkor egy egyszerú luminális-bazális elkülönítés két fehérjemarker - a luminális daganatokra jellemző GATA3 és a bazális tumorok által jellemzően termelt KRT5/6 - vizsgálatával is elvégezhető. A teljes beosztáshoz azonban még számos további (összesen 28) marker alkalmazása szükséges, melyek többek között az immun- és a stromasejtek tumoron belüli jelenlétéről adnak információt, és melyek 
szintén alapvető fontosságú információt hordozhatnak a legoptimálisabb kezelés megválasztásának szempontjából.

\section{Következtetés}

Az elmúlt 5 évben az izominvazív húgyhólyagrákok molekuláris alcsoportbeosztása kidolgozásra került. Mára közel 2000 beteg mintáin elvégzett transzkriptom szekvenálási analízisből állnak rendelkezésünkre részletes eredmények, ezért nemigen várható további, ritkább alcsoportok azonosítása. Továbbá, a klasszifikáció tekintetében megszületett széles körü konszenzus alapján valószínưsíthető, hogy abban legfeljebb már csak kisebb finomítások következnek, ezért a figyelem a továbbiakban a módszertani részletek kidolgozására összpontosulhat. A kialakított csoportbeosztás alapján egy sokkal árnyaltabb terápiás döntéshozatali mechanizmus kifejlődése várható. A jelenleg retrospektív vizsgálatok eredményeiből származó tapasztalatok a checkpointgátló kezelések hatékonyságának előrejelzése szempontjából igencsak biztatóak. A molekuláris csoportbeosztás gyógyszeres terápiában betöltött jelentőségét azonban prospektív klinikai vizsgálatoknak kell megerősíteniük, melyek eredményeit nagy érdeklődéssel és egyben reménykedve várjuk.

Anyagi támogatás: A cikk az NKFIH (FK 12443), az NVKP (16-1-2016-004) és a Bolyai János Kutatási Ösztöndíj támogatásával készült.

Szerzői munkamegosztás: Sz. T.: A téma felvetése, a kézirat megírása, a kézirat javítása. O. Cs.: Irodalomkutatás, a kézirat megírása, összeállítása, az ábrák megrajzolása. R. P., Ny. P., G. L.: A kézirat lektorálása. A közlemény végleges változatát a szerzők elolvasták és jóváhagyták.

Érdekeltségek: A szerzőknek jelen cikkel kapcsolatban nincsenek érdekeltségeik.

\section{Irodalom}

[1] Kásler M, Ottó Sz, Kenessey I. The current situation of cancer morbidity and mortality in the light of the National Cancer Registry, Hungary. [A rákmorbiditás és -mortalitás jelenlegi helyzete a Nemzeti Rákregiszter tükrében.] Orv Hetil. 2017; 158: 8489. [Hungarian]

[2] Knowles MA, Hurst CD. Molecular biology of bladder cancer: new insights into pathogenesis and clinical diversity. Nat Rev Cancer 2015; 15: 25-41.

[3] Bochner BH, Montie JE, Lee CT. Follow-up strategies and management of recurrence in urologic oncology bladder cancer: in vasive bladder cancer. Urol Clin North Am. 2003; 30: 777-789.

[4] Meeks JJ, Lerner SP. Molecular landscape of non-muscle invasive bladder cancer. Cancer Cell 2017; 32: 550-551.

[5] Niegisch G. Urothelial cancer: update on systemic treatment options. [Az urothelialis carcinoma aktuális gyógyszerterápiás lehetőségei.] Aktuelle Urol. 2017; 48: 340-349. [German]
[6] Pietzak EJ, Zabor EC, Bagrodia A, et al. Genomic differences between "primary" and "secondary" muscle-invasive bladder cancer as a basis for disparate outcomes to cisplatin based neoadjuvant chemotherapy. Eur Urol. 2019; 75: 231-239.

[7] Felsenstein KM, Theodorescu D. Precision medicine for urothelial bladder cancer: update on tumour genomics and immunotherapy. Nat Rev Urol. 2018; 15: 92-111.

[8] Comprehensive molecular characterization of urothelial bladder carcinoma. Cancer Genome Atlas Research Network. Nature 2014; 507: 315-322.

[9] Robertson AG, Kim J, Al-Ahmadie H, et al. Comprehensive molecular characterization of muscle-invasive bladder cancer. Cell 2017; 171: 540-556.e25.

[10] Damrauer JS, Hoadley KA, Chism DD, et al. Intrinsic subtypes of high-grade bladder cancer reflect the hallmarks of breast cancer biology. Proc Natl Acad Sci. 2014; 111: 3110-3115.

[11] Choi W, Porten S, Kim S, et al. Identification of distinct basal and luminal subtypes of muscle-invasive bladder cancer with different sensitivities to frontline chemotherapy. Cancer Cell 2014; 25: 152-165.

[12] Dadhania V, Zhang M, Zhang L, et al. Meta-analysis of the luminal and basal subtypes of bladder cancer and the identification of signature immunohistochemical markers for clinical use. EBioMedicine 2016; 12: 105-117.

[13] McConkey DJ, Choi W. Molecular subtypes of bladder cancer. Curr Oncol Rep. 2018; 20: 77.

[14] Kardos J, Chai S, Mose LE, et al. Claudin-low bladder tumors are immune infiltrated and actively immune suppressed. JCI Insight 2016; 1: e85902.

[15] Sjödahl G, Lauss M, Lövgren K, et al. A molecular taxonomy for urothelial carcinoma. Clin Cancer Res. 2012; 18: 3377-3386.

[16] Sjödahl G, Eriksson P, Liedberg F, et al. Molecular classification of urothelial carcinoma: global mRNA classification versus tumour-cell phenotype classification. J Pathol. 2017; 242: 113125.

[17] Seiler R, Ashab HA, Erho N, et al. Impact of molecular subtypes in muscle-invasive bladder cancer on predicting response and survival after neoadjuvant chemotherapy. Eur Urol. 2017; 72: 544-554.

[18] Kamoun A, De Reyniès AK, Allory Y, et al. The consensus molecular classification of muscle-invasive bladder cancer. 2018. BioRxiv488460. doi: https://doi.org/10.1101/488460.

[19] Sjödahl G, Abrahamsson J, Holmsten K, et al. Pathologic downstaging after preoperative cisplatin-based combination chemotherapy in immunohistochemistry-defined molecular subtypes of bladder cancer. EAU Eur Urol. 2019; 18(Suppl): e2106-e2107.

[20] Kim J, Kwiatkowski D, McConkey DJ, et al. The Cancer Genome Atlas expression subtypes stratify response to checkpoint inhibition in advanced urothelial cancer and identify a subset of patients with high survival probability. Eur Urol. 2019; 75: 961964.

[21] Hedegaard J, Lamy P, Nordentoft I, et al. Comprehensive transcriptional analysis of early-stage urothelial carcinoma. Cancer Cell 2016; 30: 27-42.

[22] Hurst CD, Alder O, Platt FM, et al. Genomic subtypes of noninvasive bladder cancer with distinct metabolic profile and female gender bias in KDM6A mutation frequency. Cancer Cell 2017; 32: 701-715.e7.

[23] Szarvas T, Oláh Cs, Reis H. Neoadjuvant cisplatin-based chemotherapy in "primary" and "secondary" muscle-invasive bladder cancer - is it a surrogate for molecular subtypes? Transl Cancer Res. 2019; 8(Suppl 2): S176-S179.

[24] Teo MY, Rosenberg JE. Refining existing knowledge and management of bladder cancer. Nat Rev Urol. 2019; 16: 75-76.

[25] Todenhöfer T, Miernik A, Seiler R. High-throughput molecular analysis of urothelial carcinoma: potential clinical applications. [Az urothelialis carcinoma molekuláris genetikai hátteránek fel- 
térképezése a klinikai alkalmazhatóság tükrében.] Aktuelle Urol. 2019; 50: 84-93. [German]

[26] Nadal R, Bellmunt J. Management of metastatic bladder cancer. Cancer Treat Rev. 2019; 76: 10-21.

[27] Siefker-Radtke AO, Currie G, Abella E, et al. FIERCE-22: Clinical activity of vofatamab (V) a FGFR3 selective inhibitor in combination with pembrolizumab $(\mathrm{P})$ in WT metastatic urothelial carcinoma, preliminary analysis. J Clin Oncol. 2019; 37(Suppl): 4511.

[28] Kim J, Mouw KW, Polak P, et al. Somatic ERCC2 mutations are associated with a distinct genomic signature in urothelial tumors. Nat Genet. 2016; 48: 600-606.

[29] Van Allen EM, Mouw KW, Kim P, et al. Somatic ERCC2 mutations correlate with cisplatin sensitivity in muscle-invasive urothelial carcinoma. Cancer Discov. 2014; 4: 1140-1153.

[30] Wülfing C, Machiels JP, Richel DJ, et al. A single-arm, multicenter, open label phase 2 study of lapatinib as the second-line treatment of patients with locally advanced or metastatic transitional cell carcinoma. Cancer 2009; 115: 2881-2890.

[31] Powles T, Huddart RA, Elliott T, et al. Phase III, double-blind, randomized trial that compared maintenance lapatinib versus placebo after first-line chemotherapy in patients with human epidermal growth factor receptor $1 / 2$-positive metastatic bladder cancer. J Clin Oncol. 2017; 35: 48-55.

[32] Siefker-Radtke AO, Kamat AM, Grossman HB, et al. Phase II clinical trial of neoadjuvant alternating doublet chemotherapy with ifosfamide/doxorubicin and etoposide/cisplatin in smallcell urothelial cancer. J Clin Oncol. 2009; 27: 2592-2597.

[33] Warrick IJ, Sjödahl G, Kaag M, et al. Intratumoral heterogeneity of bladder cancer by molecular subtypes and histologic variants. Eur Urol. 2019; 75: 18-22.

[34] Sjödahl G, Eriksson P, Lövgren K, et al. Discordant molecular subtype classification in the basal-squamous subtype of bladder tumors and matched lymph-node metastases. Mod Pathol. 2018; 31: 1869-1881.

(Szarvas Tibor dr., Budapest, Üllői út 78/B, 1082 e-mail: sztibusz@gmail.com)

\section{"Lex specialis derogat generali." (A különleges törvény érvényteleníti az általános szabályt.)}

A cikk a Creative Commons Attribution 4.0 International License (https://creativecommons.org/licenses/by/4.0/) feltételei szerint publikált Open Access közlemény, melynek szellemében a cikk bármilyen médiumban szabadon felhasználható, megosztható és újraközölhetö, feltéve, hogy az eredeti szerző és a közlés helye, illetve a CC License linkje és az esetlegesen végrehajtott módosítások feltüntetésre kerülnek. (SID_1) 